\title{
PROBLEMS AND PECULIARITIES \\ OF TEACHING UKRANIAN AS A FOREIGN LANGUAGE
}

\section{Ivetta Martynova $^{1}$}

DOI: https://doi.org/10.30525/978-9934-26-077-3-17

Abstract. The purpose of the paper is to summarize and present teaching Ukrainian as a foreign language in higher educational institutions of Ukraine. The main focus lies in the most modern methods of teaching Ukrainian for foreign students of different nationalities who attain higher education in Ukraine. The author reviewed the development of the concepts of emotional intelligence and modern approaches to the determination of the nature and forms of manifestation of empathy in individuals. Empathy is a principal social emotion; in its most general form it is defined as the individual's ability to react emotionally and to respond to other people's experiences. The author emphasizes the feasibility of accounting empathy as part of emotional intelligence, which is key to successful study of the Ukrainian language for foreigners. The value of socio-psychological training as a means to enhance students' empathy is proven. Emotional intelligence techniques for the formation and development of empathy culture are presented. The formation of students' emphatically culture promotes social and psychological training, thus enhancing competence in the field of communication and interpersonal skills to acquire. Sociopsychological training covers various methods, such as business and roleplaying, discussions and more. It involves the acquisition of psychological and pedagogical knowledge in communication, effective communication skills, for example, to get in touch, listen, persuade others and to form attitudes necessary for successful communication, such as readiness to consider the problem from another point of view; development of abilities of self-examination, to understand other students, and correction system of relations with the outside world. Other techniques appropriate to apply during the stimulation of student culture are widely known such as self-disclosure, emotional response, personal contact (physical, visual,

\footnotetext{
${ }^{1}$ Senior Lecturer,

Kharkiv National University of Construction and Architecture, Ukraine

(C) Ivetta Martynova
} 
verbal, plastic, object-efficient) jokes, humor and others. The latter are very effective in removing emotional stress, eliminating aggressive or sad states of stress in relationships, and help enhance mental activity. Jokes activate distraction and relax empathy. The development of emotional intelligence in the student regulates that individual's abilities and traits that are responsible whether the impact of emotional phenomena will be constructive or destructive behavior for the student. Developing emotional intelligence is inextricably linked to the communicative approach to language learning. The teacher should provide comfortable and effective communication between students in class, using the methods above, techniques and creating a positive atmosphere that promotes cooperation and helps develop confidence in students. Holistic education must involve the unity of intellectual and emotional areas. Also, this work is devoted to the analysis of existing classifications of dialogues, consideration of advantages and disadvantages of some of their types, to the coverage of methods of extracurricular work with students, their detailed analysis, and identification of their pluses and minuses. The model of the use of more appropriate combinations of types of dialogues is presented in order to achieve the most productive result in language learning. A model of formation of foreign communicative competence is offered. The practice of the proposed methods should allow students to unleash their potential, break language barriers, expand vocabulary, improve pronunciation, and most importantly - increase self-confidence.

\section{Introduction}

Most countries around the world have come to the conclusion that it is necessary for the individual to speak not only their own native language, but also many others, which, in turn, will indicate his or her multicultural orientation. The interest of foreigners in the Ukrainian language, the desire and need to learn it in Ukraine and abroad - these are the realities of today.

The Ukrainian language becomes a means of business relations, the language of dialogue of cultures, and the language of specialty disciplines. All this necessitates the development of modern methods and techniques of teaching Ukrainian as a foreign language, detailed elaboration of theoretical aspects of teaching and their implementation in the practice of teaching Ukrainian as a foreign language. 
Language should become a tool of communication that will allow you to penetrate into another culture, determine for yourself its characteristics and learn the type of behavior and adequate perception of representatives of another culture. Only in this way can future students become full participants in intercultural dialogue.

The relevance of the research topic is that the training of numerous groups of students, differing in mental characteristics, religious beliefs, differences in age and educational environment, requires the search for such teaching methods that would most fully realize the natural abilities of students, develop them and give them knowledge in the field of linguistics. The main principle in achieving such a pedagogical task is the problem of choosing methods of teaching Ukrainian as a foreign language and checking their effectiveness. Ukrainian is becoming the second mother tongue for certain students from Europe, North and South America, Asia, Africa representatives of almost all continents, who come to Ukraine to study. In this regard, an urgent problem for researchers of this methodology to study and improve the basic methods of teaching Ukrainian as a foreign language.

Linguistic teachers are concerned about how to provide educational material to foreign students faster, more efficiently, more diversely and more interestingly. Teaching the Ukrainian language is not an easy task. That is why new methods, techniques and forms of teaching Ukrainian as a foreign language are constantly being developed. New concepts are being created. Scientists, teachers-practitioners of educational institutions of various profiles in Ukraine and abroad are actively working to solve these problems. Their experience, scientific and educational developments help today in resolving topical issues related to the teaching of the Ukrainian language in higher educational institutions of Ukraine.

An important prerequisite for a successful educational process is the development of clear methodological foundations, principles of teaching Ukrainian as a foreign language. Many articles are devoted to general issues of methodology and ways of mastering a foreign language, the content of education determine the different directions in teaching methods and learning strategies.

Summarizing the methods of teaching a language as a foreign language, B. Sokil, for example, described in more detail the most common of them grammar-translation, audio-linguistic, communicative, and others. [10]. The 
study of the peculiarities of teaching and learning foreign languages allowed I. Slesareva to identify the linguodidactic potential of the corpora of texts, including student, and the prospect of its use in teaching a foreign language [9].

General methodological approaches to the formation of language competence in foreign students are revealed in the aspect of studying vocabulary and grammar of the language. I. Protsyk characterizes the most important methods of presentation (semanticization) of new lexical material [8].

It is the real learning conditions that determine the attention of researchers (Plotnikova G., Yakunina N.) to the formation and development of skills and abilities in various types of speech activity (speaking, listening, reading, writing). The basic linguodidactic principles of teaching types of language activity are formulated, important practical moments are described, attention is focused on the role and functions of the teacher in the educational process [7].

Teaching Ukrainian as a foreign language is impossible without taking into account the promising achievements of modern language didactics, as well as the needs of the time.

Relevant are studies on the use of illustrative descriptors of European recommendations for language education, such as in the work of A. Nedashkivska, A. Antonov [6], I. Dovgy [4], describing the study of language at the level of modern technologies (problems, methods, tools for distance learning, also very important opportunities to use internet technologies to learn Ukrainian as a foreign language).

Mastering any language as a foreign language is effective when taking into account the national-specific features of a language system at different levels. These features are especially evident at the level of vocabulary and phraseology.

Ukrainian as a foreign language is one of the sections of scientific and practical spheres of pedagogical activity engaged in teaching natural languages - language didactics. Its purpose is to study the Ukrainian language to develop methods, techniques and descriptive technologies for the possibility of teaching Ukrainian to native speakers of foreign languages.

Teaching Ukrainian as a foreign language differs from specialists in teaching Ukrainian as a non-native language. Teaching Ukrainian as a nonnative language usually means teaching the language in those regions of Ukraine where the native languages of the majority of the population are other languages, but not Ukrainian. 
The subject area of Ukrainian as a foreign language is closely related to many related scientific disciplines such as general, applied, structural and comparative linguistics, psychology of activity and learning, culturology, linguoculturology, pedagogy, ethnopsychology, history of Ukraine and general history.

In general, language acquisition is a long, time-consuming, and most importantly, individual process. The curriculum of the Ukrainian language, like other foreign languages, includes in-depth study of phonetics, grammar, and lexical structure of the language, but still the development of practical skills gives way to theoretical study. The main principle is the functional principle of studying Ukrainian as a foreign language. It is necessary to teach foreign students not only to know the basics of a foreign language, but also to teach them to communicate in the language being studied with enthusiasm and curiosity, both in their professional subjects and in various everyday situations. Students must not only understand that the language is being studied, but also correctly construct their message in response, which will correspond to the culture of the interlocutor.

Therefore, along with the study of the phenomena of language, it is necessary to study the characteristics of the cultures of the participants in the dialogue, their characteristics, similarities and differences. The study of cultural traditions is an integral part of the process of learning a foreign language, which is also a learning of interpersonal communication. In the process of working in the classroom, foreign students must confirm and defend their point of view, use reasoning, learn to analyze the content and find ways of understanding in the process of dialogue in the language being studied. This expands the boundaries of learning, and allows you to optimize the process of communication between people.

When learning a foreign language, the individualization of the educational process should be carried out at all levels in the sense that its depth and form must be adapted to the capabilities of each foreign student. The desire to put into practice the principle of a differentiated approach to the student's personality, the desire of teachers to go beyond an outdated education system have led to the emergence of new methods of language teaching with non-traditional content.

In our opinion, active teaching methods will qualitatively change the level of knowledge and increase interest in the subject. There is a lot of 
research by both domestic and foreign linguists on the basic methods of teaching foreign languages. They all have both positive and negative sides. We are close to the opinion of the American linguist Leonard Bloomfeld: "In the process of developing the theory and practice of teaching foreign languages, numerous attempts have been made to create the most rational methods of mastering foreign languages. Along with the development of the main methodological areas of teaching foreign languages, their modifications also developed. Modifications of one methodological direction are methods that are characterized by common or similar features of the main methodological direction» $[1$, p. 25].

It should be noted that only as a result of a combination of several methods we will be able to succeed. The use of certain methods of teaching Ukrainian as a foreign language depends on the specific material - phonetic, grammatical or lexical. The training of a large number of foreign students requires from teachers new approaches to the organization of teaching Ukrainian as a foreign language in higher educational institutions in order to develop language activity and skills of practical use of the language studied for professional purposes. The purpose of communication is to establish contact, persuasion of the interlocutor, which should be carried out in the form of conversation or dialogue. That is why the most priority direction of teaching material is lexical, and only then - grammatical and phonetic [4, p. 102]. Undoubtedly, the basis of such a lesson should be oral speech. It is observed from the first minutes of the lesson. In our opinion, learning grammar rules, memorizing words is only a means of mastering oral speech, as it is the best way to learn and consolidate any material.

Thus, the first method of teaching Ukrainian as a foreign language is a method of discussion (dialogue, conversation). Foreign students can ask and answer questions on local lore, social, everyday topics, be interested in the grammatical rules of the Ukrainian language. There should be a constant discussion of any concept, problem, topic, etc. Thus, there will be a better assimilation of educational material.

Traditional scheme: explanation of the teacher - notes of students reproduction by students of the material given by the teacher by traditional methods (writing of grammatical models, «direct» memorization of words and constructions, and even whole texts, performance of a considerable quantity of written exercises, etc.) - all this will not be as effective for 
understanding and using the Ukrainian language as a simple discussion, namely:

- Questions by the teacher to students on the topic of the lesson;

- Assimilation of new material (lexical, grammatical or phonetic) in the form of dialogues and monologues.

- Writing tasks should be accompanied by comments (for example: why this word is appropriate in this sentence, why this grammatical form, and not another, etc.) and error correction [3; 4, p. 108].

In our opinion, it does not make sense to constantly check written assignments (it is advisable to do this only during the final control exam of the level of knowledge of foreign students). Most students will not understand mistakes. And commenting and explaining both the teacher and the students themselves will be able to immediately identify weaknesses and strengths in their knowledge.

The pan-European recommendations on education note that the main educational goal is to prepare foreign students for life in a democratic society by introducing methods of teaching disciplines that stimulate the independence of thought, judgment, encourage responsible competence. In this regard, it seems to us quite appropriate to introduce the study of the discipline of the Ukrainian language as a foreign educational design technology.

Thus, the second method is the design method. With its help you can perform many tasks and more effectively succeed in learning Ukrainian as a foreign language.

You can work with foreign students on the following projects:

1) video; 2) interviews and questionnaires on various topics which are designed in the form of tables or presentations; 3 ) city tour (script creation, video recording of the tour, self-dubbing of the video); 4) project work directly related to the professional sphere of students' activity.

You can also develop a project «Book of rules of Ukrainian grammar». International students make cards in which they create a schematic representation of various grammatical constructions and rules. Then these cards are folded into appropriate envelopes, which are pasted into special notebooks or folders «books of rules of Ukrainian grammar.» Thus, according to the very idea of educational design technology, the role of the teacher is to promote the development of critical and creative thinking of students. 
The third method is the listening method. In the method of teaching a foreign language, listening was considered a passive type of speech activity. Only thanks to the research of American scientists J. Asher and S. Krashen, whose ideas formed the basis of popular modern methods of learning foreign languages (comprehension before reproduction), listening has become an active type of speech activity. The process of developing listening skills involves the following three programs:

1. Listening when introducing new material, when the sound reproductions of new language elements are formed especially intensively. In this program much attention is paid not only to the understanding of the audio, but also the conscious perception of phonetic and acoustic features of these language units.

2. Listening as an element of dialogic speech. This program is basic in terms of developing speaking skills and is actually due to the need - without listening there is no communication.

3. Listening as a special type of exercise, i.e. as a special program. It is about listening to the language of a teacher or speaker, which includes both dialogues of different people and monologue units (stories, reading stories, etc.).

The act of listening is based on the educational and language situation [11, p. 16]. Its subject is the content of the listening text, and the communicative task expresses the purpose of listening. These are the key components that define communication. Listening, like any other language act, is preceded by awareness and acceptance of the need for it. Thus, using the method of listening, the teacher not only teaches students to perceive language by ear, but also develops students' language.

The fourth method is the role-play method. Role-play is an active method of learning, a means of developing students' communication skills. Roleplay is closely connected with the interests of foreign students, it is a means of emotional interest of students, motivation of their educational activities.

Role-playing games are an active method of teaching practical knowledge of a foreign language, helping to overcome students' language barriers, significantly increasing the amount of language practice of foreign students. In other words, it is learning in the process of discussion. Today there are many different types and forms of role-playing games in foreign language classes. Especially the method of role-playing helps in the study 
of new lexical topics. For example, you can use the role-playing game «at the interview», where students take on the role of employer and employee.

\section{Emotional intelligence in learning the Ukrainian language}

One of the most important tasks of learning Ukrainian as a foreign language is to educate a person who is able and willing to take part in intercultural communication, successfully pass socialization and establish harmonious relations with the environment. In Ukrainian language classes, it is possible to model different communicative situations, which allow foreign students to practice certain patterns of behavior in different speech situations.

Many scholars in the field of linguodidactics believe that the connection of the emotional sphere of the student during the study of language contributes to its more successful acquisition and, in turn, affects the formation of the student's personality. Modern experts are trying to develop a comprehensive approach to teaching a foreign language, including Ukrainian as a foreign language, using components of emotional intelligence, such as empathy. And emotional intelligence is an important component of successful communication and can develop only during communication, which is modeled in Ukrainian language classes.

The purpose of the monograph is to try to substantiate the expediency of taking into account empathy as a component of emotional intelligence in teaching Ukrainian as a foreign language. The task of our study: to consider the development of ideas about empathy and modern approaches to determining the nature, forms of empathy, to determine the role of empathy in the development of student personality, to justify the importance of sociopsychological training as a means of increasing student empathy.

Traditionally, in art, literature and everyday life, the humanization of human relations is associated with compassion, the ability to understand another person and to absorb his problems and joys. In psychology, these most important abilities are summarized by the concept of «empathy».

Empathy is a leading social emotion and is most generally defined as the ability of an individual to react emotionally, to respond to other people's experiences. Empathy involves the subjective perception of another person, penetration into his inner world, understanding of his experiences, thoughts and feelings. The concept of «empathy» as a psychological phenomenon 
is borrowed by scientific psychology from the philosophy of the early twentieth century. At that time, in the philosophical sciences such as ethics and aesthetics, this term was the identical equivalent of «sympathy.»

Empathy as a communicative property of the student's personality contributes to the solution of various issues and opens new opportunities for a more effective influence on the person's personality in communication. It is one of the regulators of the relationship between students and teachers, is manifested in the desire to provide assistance, support to other students, promotes the development of humanistic values of the student's personality.

Analysis of research and publications: The theoretical basis of our research is the work of such scientists as T.P. Gavrilova, V.V. Polyakova, S.I. Samigin, T.G. Nikulenko, S.A. Sushchenko and others. The concept of empathy was introduced into psychology by Thatcher in 1903. Modern researchers interpret it as an emotional phenomenon, and as a process of understanding, and as «entering» another person, in his thoughts and complicity in his experiences. In other concepts (V.M. Banshchikov, V.Y. Zavyalov, U.P. Korolenko) empathy is seen as a comprehension of the inner life of man, not accompanied by experiences, i.e. as an intellectual process or understanding. However, psychologists Diamond and Bronfebrenner, who studied empathy as understanding, showed the connection of this process with the emotional characteristics of the individual. In their interpretation, empathy is social sensitivity, or social insight, i.e., the ability of an individual to recognize the thoughts and feelings of another person.

The difference in the interpretation of empathy as a cognitive and emotional phenomenon is largely due to the fact that both the process of understanding and empathy are related to both those and other aspects of cognition. Both of these processes are not only different ways of knowing the inner world of man, but also have different structures and functions in behavior. If understanding is a process of intellectual analysis of another person's behavior, then empathy is a process of emotional participation in other people's experiences.

Empathy is present in all types of interpersonal communication. It is the foundation of the socio-psychological environment in which empathy is born, developed and manifested. Empathy in students promotes more effective mutual knowledge and, in particular, knowledge of states and experiences, it enriches their own emotional experience, develops personality and its 
value system, performs protective functions, if, for example, the experience threatens the mental balance of the student. An empathetic person recognizes, perceives and approves the uniqueness and self-worth of the «I $»$ of another person. Empathy provides an opportunity for self-disclosure and support. Students with a high degree of empathy have such traits as openness in communication, softness, tolerance, friendliness, sociability, emotionality, and students with a low degree of empathy show isolation, hostility, aggression, criticism of the shortcomings of others. The system of attitude of an empathetic student to another student encompasses a sincere interest in him, understanding the significance and value of his personality, and does not allow alienation and indifference to the experiences of others.

The formation of empathic culture of students is facilitated by sociopsychological training, which allows for increased competence in the field of communication and acquiring of interpersonal communication skills. Sociopsychological training covers various methods, such as business and roleplaying games, discussions, etc. It involves the acquisition of psychological and pedagogical knowledge in communication, effective communication skills, such as getting in touch, listening, persuading, etc., as well as the formation of guidelines necessary for successful communication, such as willingness to consider the problem from another angle; development of abilities for self-analysis, the understanding of other students and correction of the system of relations with the surrounding world.

The business game is based on a problem situation, which should, with a high degree of reality, mimic the specific conditions and dynamics of actions that ensure the inclusion of participants in a particular situation and their mastery of professional roles. The main features of the educational business game are modeling the process of the teacher and students in terms of the problem and the distribution of roles between the participants of the game. Within the game, dialogic communication develops, which contributes to the formation of empathy as a personal, professionally significant quality of the student.

\section{The role of dialogue in foreign language teaching}

Dialogue as a complex and multifaceted linguistic phenomenon has been of interest to linguists since the beginning of the twentieth century, as it is a concrete embodiment of language in its specific means, a form of human speech activity and, in a broad sense, a form of language existence. 
Our attention to dialogue is due to the practical need to create materials for compiling a collection of dialogues in the Ukrainian language for foreign students. It is also important to determine the principles of construction of the collection, the location of dialogues and to take into account the peculiarities of dialogic communication.

Scientists $[1 ; 2 ; 5]$ offer different classifications of dialogues taking into account various factors. In recent years, researchers of dialogic speech have focused mainly on the functional-communicative description of dialogue, i.e. analyze dialogic speech from the standpoint of interaction of communicators. Differentiation of dialogues depending on their semantics allowed researchers to distinguish such types of dialogues as informative and evaluative $[21 ; 22]$. The scientific literature considers $[21 ; 22 ; 23]$ four main types of dialogues: 1) associative conversation (dialogueconversation), the purpose of which is the exchange of thoughts, feelings, maintaining a conversation on the basis of related topics. The rules of this method of dialogic communication provide for the avoidance of repetition, time limitation of remarks and equality of communicative instructions of speakers; 2) dialogue-solution of the problem is characterized by continuity of the topic, equal interest of partners in making a joint decision, careful design of statements and the possibility of repetition and clarification; 3) dialogue-questioning, during which the roles are quite clearly divided into the one who asks and the one who answers; it is possible to evade the answer, use a counter-question, discuss the question, but detailed, inadequate answers, as well as repeated answers are prohibited; 4) dialogue-clarification of misunderstanding (similar to dialoguesolution of the problem due to the presence of purpose, careful design of statements and similar to dialogue-questioning through the use of questions and answers).

Situationally conditioned learning of dialogic speech during classroom classes with foreign students, in the conditions of direct communication is the main means of achieving the goal, i.e. the formation of communicative competence. The use of artistic texts, drawings and photographs makes the lexical material clear and facilitates its assimilation. In our opinion, it is necessary to form in a foreign student (both a future philologist and a nonphilologist) the ability to conduct the main types of dialogue: dialoguequestioning, dialogue-conversation and dialogue-discussion. 
The simplest in structure is dialogue-questioning, as it consists of logically consistent questions and answers. If it is professionally oriented, it is characterized by the presence of a single specific topic. This type of dialogue on a domestic topic is not characterized by such thematic unity. The answers to the questions can vary from concise to detailed. Dialogue questioning teaches the foreign student how to ask questions, clarify information from the interlocutor, to express doubts (uncertainty, satisfaction) and to be understood.

In the dialogue-conversation speech occurs at a slow pace, characterized by detailed remarks. During the conversation, some of the remarks of an individual participant may take the form of a short monologue (for example, a short monologue-description, monologue-story and monologuereasoning). During the dialogue-conversation the ability to start a dialogue should be formed, using the appropriate initiative cue, the ability to respond quickly to the interlocutor's cue, using cue with different communicative functions, the ability to maintain a conversation, adding to the cue-response initiative; the ability to stimulate the interlocutor to speak, expressing their interest through remarks of evaluative or descriptive nature. This can be done by working in pairs of small or large groups.

The ability to conduct a dialogue-discussion in this specialty allows for creation of conditions of creative tension, the result of which is the oral expression of each student. Upon completion of the dialogue-discussion course, students should be able to argue their point of view using emotional and modal expressions; formulate conclusions; politely disagree with the opponent's opinion and offer your vision of the problem.

Regarding the structure of dialogue: the elementary material of the form of speech communication is the cycle, created, via meaning, by two interconnected basic parts of speech which act as communicators. The dialogue cycle is mostly related to a specific topic. Within one cycle, each of the communicators can say not one, but several elements (this is a complex dialogue cycle). Dialogic speech is characterized by peculiar temporal dynamics: it is characterized by a small gap between the cues of communicators. In direct live communication, the timeliness of the reaction is an important condition for the psychological comfort of communication partners.

There are different ways to teach dialogue. For example, there are deductive and inductive ways of teaching dialogue. The deductive way 
involves starting to learn the dialogue by listening to the sample. Then this sample is read by students. During the reading the intonation is fixed, then the dialogue is played out by roles and memorized. The inductive method involves the way of mastering the elements of dialogue, and then - the formation of skills and abilities to build it independently on the basis of educational and speech situations.

The technology of teaching dialogue contains the following stages: 1) presentation of the sample not for the purpose of learning, but for the purpose of imitation; 2) training in dialogue planning; 3) learning to deploy the content of the dialogue in accordance with the communicative purpose; 4) combining cues by purpose, function, modality. Memorization leads to leaning only clichéd dialog components related to address, greetings, etiquette. An important methodological task during the training of dialogue is not so much mastering the speech reaction to the supporting cue, as the ability to initiate a dialogue based on the situation and it changes. Mastering the dialogue takes place with the help of both language (preparatory, training) and with the help of communicative-speech exercises. Exercises of language nature can be imitation (without transformation of the sample, with a slight modification of the sample), modification of expressions (substitution, expansion, reduction, etc.), synonymous and antonymous substitutions, combining and grouping words, sentences; building a dialogue by analogy and exercises that contain questions and answers. Dialogue plays an active role in the development of oral skills. In dialogues, students can use a large number of newly learned terms, phrases, to bring their use to automatism. The specificity of the dialogue is that this form involves a fairly rapid change in the actions and reactions of people interacting with each other.

Researchers note such features of dialogue as rapid exchange of information, during which each component there is a cue, although the structure of the cue may not be connected. The feature of the dialogue that determines its grammatical structure is situationality, i.e. all participants know the subject conversation and its content. The situationality of the dialogue implies the possibility of incomplete expression. In part, replicas can be dropped or added without losing content.

Dialogic language is characterized by the active use of nonverbal components of communication (facial expressions, gestures, pauses, intonation). The strength, intonation, and timbre of speech also play a 
significant role in fostering the perception and understanding of dialogue. The behavior of another communicator (the listener) has a certain significance during the dialogue. The first communicator perceives the facial expressions of another, feeling its influence on his speech process. Dialogue is also characterized by a kind of time dynamic: the remarks have a small gap between each other, so timeliness of reaction is very important and serves as an important condition for the psychological comfort of partners involved in the communication. Researchers of dialogue [2] distinguish its different types, the main types of which are: 1) dialogue of equal partners on the question-answer model; 2) relay race, sequence of statements determined by communicators; 3 ) inclusion in the dialogue of memories of previous dialogues; 4) dialogue takes place in a certain scenario aimed at achieving a certain goal; 5) dialogue is built by revealing mainly interpersonal relationships, emotions, the will of communicators and conflict resolution in various fields.

Dialogic communication as a method covers various emotional and intellectual techniques that contribute to the formation and development of empathic culture of the individual, such as identification, cognitive interpretation, summary, «mirror» and more. Identification is to transport yourself into the situation, the position, of another person. It helps to understand the inner state, intentions, motives and feelings of another person. Cognitive interpretation involves assisting the interlocutor in explaining those aspects of the situation that he or she cannot comprehend or explain. Summarizing allows you to connect fragments of the conversation, to give them meaningful unity. This technique gives confidence in the accuracy of perception of the interlocutor's message and helps the student to understand how well he managed to convey his opinion.

Reception «mirror» is to repeat the last phrase with a change of word order. This technique helps the interlocutor to comprehend his own statement and aims to establish mutual understanding. Repetition of the last words of the interlocutor is a kind of reception «mirror», which is called «moon». It performs the function of clarifying the statement and does not involve the continuation and development of the student's opinion. When interacting with a student, you should refer to him more often, calling his name, i.e., use the technique of «Proper name», which does not always cause a student's sense of satisfaction. Encouragement and reassurance are ways to confirm 
that the teacher is willing to accept the student's thoughts and feelings no matter what they are («Yes, I understand your condition», «Keep going, keep going. It's interesting», «Nice to hear»). These reactions reduce the student's tension, which arises from the fear of being misunderstood or rejected. It is also necessary to use clarifying questions aimed at clarifying the views, opinions, perceptions of the student. These questions do not evaluate the student, they help to make his statements more accurate and understandable, as well as encourage further statements. Among other techniques that should be used to stimulate the development of emphatic culture of the student, there are such as self-disclosure, emotional response, jokes, humor and others. The latter are quite effective in relieving emotional stress, eliminating a sad or aggressive state, emphasize friendliness in relationships, promote the activation of mental activity. The joke activates, distracts, relaxes, gives birth to empathy.

\section{Conclusions}

Experience shows that there is no one ideal method for learning Ukrainian as a foreign language. In practice, in the process of teaching Ukrainian as a foreign language, most methods are combined and used. The new vision of education aims to create a motivational environment for students in the process of learning Ukrainian as a foreign language. Therefore, today, teachers need to constantly improve their knowledge of foreign language teaching methods, implement the latest educational concepts in their teaching practice and keep up with the times. It is the use of innovative technologies of teaching foreign languages that allows you to create the right atmosphere in the classroom, helps to awaken the creative abilities of students, develops their thinking and forms in them the skills necessary for modern society. At the same time, the paradigm of learning is changing, and more attention is paid to the formation of skills and abilities to independently acquire knowledge in terms of research activities.

Dialogue deserves more attention from the authors of textbooks, textbooks on the Ukrainian language for foreign students, as well as teachers who directly create conditions for learning communication. This form should be used more actively for language learning. It is useful to present dialogues at the beginning and end of the lesson in order to consolidate the oral lexical and grammatical material, the development of students' speech 
skills. Dialogue should also be introduced into educational texts. Dialogue is an effective means of eliminating shortcomings in the teaching of oral speech, such as unsatisfactory level of oral speech communication, lack of dynamics of complication of the lexical and grammatical aspect of speech and non-progressive development of students' speech skills.

The approach to the student's emotional abilities as a certain competence that can be developed allows us to talk about such a phenomenon as emotional competence, and the ability to empathically include it in people's experiences is one of the components of the empirical model of the concept of emotional competence.

It is also necessary to develop the student's emotional intelligence individual abilities and traits that are responsible for the extent to which the impact of emotional phenomena will be constructive or destructive to student behavior. The development of emotional intelligence is inextricably linked with the communicative approach in language learning. The teacher must ensure comfortable and effective communication between students in the classroom, applying the above methods, techniques and creating a positive atmosphere that promotes cooperation and helps to develop confidence in students. Holistic education should provide for the unity of the intellectual and emotional spheres. The proposed comments on dialogic speech can provide an opportunity to properly organize the training of students of dialogic speech, necessary for direct communication on household and educational topics, and for professional communication.

The raised problem requires the continuation of theoretical research, in particular the development of a comprehensive approach to the study of Ukrainian as a foreign language using all components of emotional intelligence. The use of innovative technologies in teaching strengthens the connection between subjects, promotes the creation of new integrated courses and the establishment of links with international educational standards.

\section{References:}

1. Bloomfield L. (1967) Kratkoe posobie po prakticheskomu izucheniyu inostrannykh yazykov. Metody obuchenya inostrannomu yazyku za granitsey [A short guide to the practical study of foreign languages. Methods of teaching foreign languages abroad]. Moscow. (in Russian)

2. Buzalskaya E.V., Lyubimova N.A. (2014) Posobie po razvitiyu tvorcheskikh umeniy pis'ma i govoreniya u inostrannykh studentov [Handbook for the develop- 
ment of creative writing and speaking skills in foreign students]. Moscow: Zlatoust. (in Russian)

3. Byakovskaya N. (2014) Rol' situatsionnykh uprazhneniy v prepodavanii inostrannykh yazykov [Role situational exercises in teaching foreign languages]. Moscow. (in Russian)

4. Dovgy I. (2015) Metody prepodavaniya yazyka kak inostrannogo [Methods of teaching a language as a foreign language]. Moscow: KAR. (in Russian)

5. Kapinova E. (2012) Neverbal'nye sredstva v delovom obshchenii i obuchenii [Nonverbal means in business communication and learning]. Moscow: LAP Lambert Academic Publishing. (in Russian)

6. Nedashkivska A., Antonov A. (2014) Vuzovskaya metodika prepodavaniya lingvisticheskikh distsiplin: Uchebnyy posobnik [University methods of teaching linguistic disciplines: Tutorial]. Moscow: Flint Science. (in Russian)

7. Plotnikova G.M. (2011) Lingvometodicheskie osnovy obucheniya slovoobrazovaniyu [Linguistic and methodological bases of word formation teaching]. Moscow: Librokom. (in Russian)

8. Protsyk I. (2006) Yazyk i kul'tura v filologtcheskom vuze. Aktual'nye problemy izucheniya i prepodavaniya [Language and culture in philological university. Current issues of study and teaching]. Moscow: Filomatis. (in Russian)

9. Slesareva I.P. (2010) Problemy opisaniya i prepodavaniya leksiki [Problems of describing and teaching vocabulary]. Moscow: Librokom. (in Russian)

10. Sokil B. (2012) Khrestomatiya po metodike prepodavaniya yazyka kak inostrannogo [A textbook on methods of teaching a language as a foreign language]. Moscow: Courses. (in Russian)

11. Fedotova N.L. (2013) Metodika prepodavanya russkogo yazyka kak inostrannogo [Methods of teaching Russian as a foreign language]. Moscow: Zlatoust. (in Russian)

12. Yakunina N. (2012) Resursy Interneta pri obuchenii chteniyu inostrannykh studentov [Internet resources in teaching reading to foreign students]. Moscow. (in Russian)

13. Basova A.G. (2012) Ponyatie impatii v otechestvennoy i zarubezhnoy psikhologii [The concept of empathy in domestic and foreign psychology]. Young Scientist, no. 8, pp. 254-256.

14. Ilyin E.P. (2011) Motivatsiya i motivy [Motivation and motives]. Petersburg: Peter. (in Russian)

15.Kaigorodov B.V. (2012) Formirovaniya ponimaniya drugogo cheloveka v protsesse professional'nogo stanovleniya psikhologov [Formation of understanding of another person in the process of professional development of psychologists]. Vector of Science of Togliatti State University. Series: Pedagogy, psychology, no. 12 , pp. $128-131$.

16. Makarova I.A. (2013) Inklyuzivnoe obrazovanie, tolerantnost',empatiya: granitsy peresetseniya. Aktual'nye zadachi pedagogiki [Inclusive education, tolerance, empathy: boundaries of intersection. Actual tasks of pedagogy]. Chyta: Young scientist, pp. 129-132.

17. Suturina Y.V. (2008) Empatiya kak professional'no znachimaya sposobnost' individuuma [Empathy as a professionally significant personality trait]. Bulletin of Buryat State University, no. 5, pp. 108-113. 
18. Demyanenko M. (1976) Osnovy obshchey metodiki izucheniya inostrannykh yazykov [Fundamentals of general methods of learning foreign languages]. Kyiv: Higher school. (in Russia)

19. Turchinova G.V. (2005) Obuchenie monologicheskomu i dialogicheskomu govoreniyu studentov pedagogicheskikh pofessional'no-lingvisticheskikh spetsial'nostey [Teaching monologue and dialogic speech to students of pedagogical professional-linguistic specialties]. Foreign languages, no. 2, pp. 43-47.

20. Drozdova I.P. (2010) Kriterii podbora tekstov dlya obucheniya professional'nomu govoreniyu studentov nefilologicheskogo profilya v VNZ [Criteria for selecting texts for teaching professional speech to students of non-philological profile in higher education]. Teaching languages in higher educational institutions at the present stage. Cross-curricular links, no. 16, pp. 69-76.

21. Valyusinskaya Z.V. (1979) Voprosy izucheniya dialoga v rabotakh sovetskikh lingvistovy. Sintaksis teksta [Questions of studying dialogue in the works of Soviet linguists. Syntax of the text]. USSR Academy of Sciences. Institute of Russian Language, pp. 299-313.

22. Mashbits E.I., Andrievskaya V.V, Komissarova E.Y. (1989) Dyalogh v obuchajushhej systeme [Dialogue in the training system]. Kyiv: Higher school. Main Publishing House. (in Russian)

23. Skalkin V.L. (1981) Osnovy obucheniya ustnoy inoyazychnoy rechi [Fundamentals of teaching oral foreign language speech]. Moscow: Russkij yazyk. (in Russian)

24. Suchych S.A. (1994) Metodologiya i metody issledovaniya dialoga. [Methodology and methods of dialogue research]. Dialogue through the eyes of a linguist. Krasnodar, pp. 39-47.

25. Turchinova G.V. (2005) Obuchenie monologicheskomu i dialogicheskomu govoreniyu studentov pedagogicheskikh professional'no-lingvisticheskikh spetsial'nostey [Teaching monologue and dialogic speech to students of pedagogical professional-linguistic specialties]. Foreign languages, no. 2, pp. 43-47. 